\title{
Reflections on Leaving Facebook
}

\author{
David W. Hill
}

On 13 August 2009 I deactivated my Facebook social networking account. The world remained on its axis but Facebook's slightly sinister prediction that my friends would miss me turned out to be correct. A torrent of e-mails and text messages arrived in the days following, asking where I had gone. Many asked me to justify why I left, some out of curiosity and some out of shock. Besides the mundane reasons - such as the ongoing project of limiting procrastination - two substantial arguments developed to explain my deactivation. These relate to voyeurism and the extension of advanced capitalism into the everyday, and are predominantly informed by the work of Zygmunt Bauman and Jean-François Lyotard respectively. In this short essay I will reflect on these themes of voyeurism and what Lyotard calls 'the inhuman', sketching out arguments/observations that contributed to my decision to leave Facebook.

\section{Voyeurism}

Zygmunt Bauman (2008b) has well described the voyeuristic nature of contemporary society. His reversal of the dystopian dictate, 'Big Brother is watching you', is a powerful slogan for postmodern times: now we are watching Big Brother. This signifies a reversal of orientation with regards the transgression of the public/private divide; when before fears existed about the public sphere invading that of the private, now it is the case that private concerns invade the public. And so we have a celebrity obsessed popular culture, where Paris is a person not a city, as Tara Brabazon (2008: 47-49) slyly observes, and a system of politics where personal matters seem to outweigh policy decisions in terms of importance-or at least media coverage. Facebook is very much part of this phenomenon. Enter 'Facebook' and 'privacy' into a search engine and thousands of stories of breaches will appear. From the position of the person posting the content, there are numerous articles outlining how this confusion of the public and private can have disastrous consequences. Perhaps most comically, and also most worryingly, the man due to become head of MI6 (the British Secret Intelligence Service) in November 2009 recently caused a stir when personal information about himself and his family was posted on Facebook-including, comically, pictures of himself in swimming trunks and, worryingly, details of his and his family's location (see http://news.bbc.co.uk/1/ hi/uk/8134807.stm). It seems that even those who should know best the value of privacy are caught up in the alluring pull to present themselves through new media.

However, this is not one of my main concerns with Facebook. Or at least, the orientation is not right. What most concerns me is not primarily a privacy issue, in the sense of concerns about the availability of one's private information in the public domain — though this is a part of it. Instead, I will describe a psychological problem that results from an ontological consideration of identity online and a phenomenological account of encountering the other (user). As Ken Hillis (2009) shows, the online avatar — and I use this term loosely to include the Facebook profile - is not identical with the user. Although the user identifies with this avatar, there is a distance maintained between the two; the avatar is a middle-ground between image and agent. This is a simple point. However, things start to get more complicated when we consider what this means for encounters between users. If the user is not identical with their avatar, then they are in a relation with only that avatar and the other user's avatar when communicating or 
interacting online. The other user, who is not identical with their avatar, remains closed off from the user (given the phenomenological orientation of the relationship from the user (the "I")).[1]

In terms of voyeurism, the result is, I believe, that the main issue is not that of the user being watched, but of the user doing the watching. Let me explain. First, it is obviously the case that users can control what content they post on their profiles. Second, given that the avatar is not identical with the user, what is being seen by the voyeur is not only controlled content but exists at a remove from the other user. As such, the other user remains out of sight; the user cannot enter into a direct relation with the other user, only with the other user's avatar.

Given these conditions, the problem of voyeurism lies in the direction of voyeurism from the user to the other user's avatar; again: it is the watching not the being watched that is the main cause of concern. Facebook allows us to gather substantial amounts of information about other people — people we know to varying degrees. More than this, it makes possible the monitoring of communications between different people, communications that may or may not have anything to do with the person who has access to them. Also, and perhaps the most uncomfortable element, it is possible to see the photograph albums of users who are not 'friends' - in either the traditional or Facebook sense of the word - if they are commented upon by those who are. We are in danger of sleepwalking into a state of voyeurism, whereby we cease to see the difference between what ought to be seen and what can be seen. Without wanting to exaggerate the point, this somnambulist voyeurism represents a perturbing psychological phenomenon; this desire/need to watch others is a disturbing anxiety, an unhealthy and inauthentic relationship with others.

A note on terminology: voyeurism through Facebook is not 'stalking' but, rather, 'lurking', to use Barry Wellman and Milena Gulia's (1999: 180) apt term. Wellman and Gulia employ this epithet to describe individuals who read users' posts online but who do not themselves contribute to the group, their having read this information thus remaining unknown to others. I suggest 'stalking' - a popular descriptor for such activity in the Facebook 'community' should be eschewed in favour of this more accurate appellation. Stalking suggests mobility, whilst lurking better connotes the sedentary nature of the activity. This immobility is an inevitable consequence of the nature of the technology; granted, mobile technologies proliferate, but the other user's profile/avatar remains stationary. Mobility is not central to Facebook voyeurism.

This is not, I hope, mere pedantry. Paul Virilio, in his provocative Open Sky (1998), reflects that our being stationary at the point of terminals is leading us quickly (it is always at speed with Virilio) to a 'spastic immobility'; nomadic man becomes sedentary man, fashioned in the image of the paraplegic. Virilio uses this as a launch pad for a critique of our unthinking use of and reliance on new technologies, and to lament the decline of face-to-face interaction. Now, it seems to me that new technologies, including Facebook, allow us to manage our face-to-face interactions in new ways, rather than negate them. But in an attempt to alight upon that which is useful in Virilio's text, I suggest that we should acknowledge the importance of immobility when considering the use of new technologies.

Slavoj Žižek, in his no less provocative Violence (2008), notes that our tolerance towards others is counterpointed by an 'obsessive fear of harassment. In short, the Other is just fine, but only insofar as his presence is not intrusive' (ibid.: 35). Organising relations today is an uneasy notion of tolerance:

My duty to be tolerant towards the Other effectively means that I should not get too close to him [...]. What increasingly emerges as the central human right in late-capitalist society is the right not to be harassed, which is a right to remain at a safe distance from others (ibid.).

The lurker remains at a safe distance from others. The lurker does not approach the other, there is no risk of an encounter; s/he is immobile. Our duty not to get too (physically) close to others is fulfilled by a mode of voyeurism that is immobile — thus negating the risk of unexpected encounters with others — and at-a-distance. Facebook lurking is the logical result of what Žižek describes as 'the central human right in late-capitalist society'; it is acquiescence to the unhealthy — unethical — situation in which people demand to avoid encounters with others.

\section{The Inhuman}

Bauman's theoretical considerations of community provide another useful point of departure for the present discussion of Facebook. The subtitle to his Community (2008a) speaks volumes: Seeking Safety in an Insecure World. This insecurity can be taken politico-economically; this is the era of 'global war on terror' and financial 
crisis, after all. But more fundamental to Bauman's considerations is the ontological insecurity of postmodernity, or 'liquid modernity' in his currency. It is a curious paradox that the flux and fluidity of postmodernity results in our 'seeking shelter' in conservative forms of identity. As Bauman notes of 'really existing community' (ibid.: 4), which is markedly contrasted with the sepia tinted nostalgic image of the community that probably never was, security is achieved at the cost of freedom. If we want confidence within community then we must cease to trust those outside of it; if we want mutual understanding within community then we must cease to speak to those outside of it; and for safety, keep the strangers out all together. The gated community or fortified residential area exemplifies this. There are two important points here: firstly, that there is no inclusion without exclusion; and secondly, that those included are oppressed. It is in this respect that communities are a conservative expression of identity, a stable island adrift in the uncertainty of liquid modernity.

Saul Newman, in his Unstable Universalities (2007), makes a similar point to that of Bauman. Newman's project here is to reinstate universality to radical politics by surveying the interplay of the singular and universal in the work of poststructuralist, or more accurately 'post-Althusserian' (ibid.: 34), thinkers such as Jacques Rancière, Alain Badiou, and Slavoj Žižek. His argument here is that the radical Left has declined because its essentialist foundations have been pulled out from under it by the postmodern critique of Enlightenment values. Curiously, and once again paradoxically, the postmodern opposition to metanarratives that makes possible fluid forms of identity results in reality in our seeking safety in reinforced stable and oppressive forms. This time, in the political sphere, we see the present hegemony of neo-conservatism and, after the death of God, His rebirth in Islamic fundamentalism and the Religious Right in America.

What has this got to do with Facebook? Well, is not the same kind of process identifiable in social networking? Much could be said of the nature of community online, though this is not my intention here. The emergence of online extremism would be another fruitful line of inquiry. But my suggestion here is more fundamental to the nature of social networking, and Facebook in particular; that is, that identities displayed here are conservative in nature. Postmodern identity is unfixed; in an unstable world, it is incorrect to assume that we however remain same. Heraclitus and Cratylus taught this to Nietzsche; Nietzsche, in turn, taught this to twentieth century continental philosophy: the self is a flow of becoming. The Facebook profile, I contend, is a palliative to this ontological insecurity. It remains more or less fixed, and what is fixed is conservative in nature. Users give standard items of identification such as their name, date of birth, photograph, hobbies and interests, etc.; this safe expression of identity neglects the radical potential for new and/or multiple identities. Granted, these items of information can change — though it is unlikely for certain elements, such as ones name, to be changed. As such, there is always a central identity to a changing Facebook profile. For example, the photograph may be updated regularly, but the proliferation of snapshots is not illustrative of flux but rather a series of exposures to fixity; the photographs overlap and point to a common feature; taken together they offer a fixed presentation of self. Where postmodernists, feminists in particular, saw the potential for the Internet to display fluid or multiple identities, there is, instead, on the whole, a conservative reaction.

What I have characterised as conservative forms of identities, from the user's perspective an attempt, whether recognised or not, to find stability amongst the volatility, are from a wider perspective better understood as standardised forms. Whether the user realises it or not, the desire for ontological security in reality results in a form of ontological violence; singular identities are translated into units of information — in effect, made same. JeanFrançois Lyotard understood this process well. In his The Inhuman (2004) Lyotard describes how things are made exchangeable by their translation into information. The thing itself is subject to a twin process of delocalisation and detemporalisation. Thinking of the user's profile, we can see how these processes aid the desire for a fixed identity. If the world is insecure then delocalisation adds stability. If identities are unstable then they are unstable over time; detemporalisation removes this danger. The Facebook profile is a still shot, an identity fixed and reinforced against risk. But more than this, Lyotard describes how these processes make the information exchangeable and interchangeable:

After they have been put into digital form, these items of data can be synthesized anywhere and anytime to produce identical chromatic or acoustic products (simulacra). They are thereby rendered independent of the place and time of their "initial" reception, realizable at a spatial and temporal distance: let's say telegraphable. (ibid.: 50).

Prised from their unique time and space in order to be made transmissible, what is now information is shorn of 'local and singular experience' (ibid.: 64). This telegraphic culture generalises and destroys. Of course, it creates as it destroys; and what it creates is a standardised, packaged piece of information. The Facebook profile is one such 
package.

Standardised; commodified: the two are closely linked. The user's identity, translated into a profile, rewritten into a form easily digestible by Facebook's advertisement software, speeds up the functioning of capitalism. Needs/ desires can be instantly identified by the algorithmic processing of personal information, and Facebook Beacon, launched in 2007, can then deliver the correlating advertisements for goods or services directly to the user (see http://en.wikipedia.org/wiki/Facebook_Beacon). In many instances the services will be online, further speeding up the process. This is frictionless capitalism and the new media technologies are complicit.

Many recent studies demonstrate the value of information in other instances (see Burrows \& Ellison 2004; Burrows \& Gane 2006; Parker, Uprichard \& Burrows 2007), and Nicholas Gane and David Beer (2008: 48-49) have begun to sketch this phenomenon in relation to Facebook. Information about who lives where, for example, can be used to target consumers directly with goods and services such that the process is more efficient — 'the fantasy of friction-free consumption' (Crang \& Graham 2007: 794). A wealthy area might be worthy of a new bank, whilst a poorer area would not; services begin to be distributed unequally. Once information is fed into a computer it can be 'software sorted' (Graham 2005) with the result that contemporary capitalism is not only maintained but extended. As such, many new technologies — including new media in general and Facebook in particular — are complicit with the extension of advanced capitalism into the everyday.

And so the user's profile becomes a desirable commodity, a goldmine for revenues sought by big business. With web 2.0 users are supposed to shape content; but with Facebook, it is the users' identity that is shaped — and then packaged and sold. Here we see what Lyotard calls the inhumanity of techno-scientific development.

\section{| Concluding Remarks}

So: I left Facebook. I have attempted to sketch above the reasons for my deactivation, though this is by no means a complete picture. There are many avenues here for further research, some of which I will pursue in my own work. What I hope to have done is translate what are almost reflex reactions into something with theoretical rigour, to reflect critically on what was a fairly banal occurrence. If I may be so bold, the take-home message here would be that when the distinctions between public and private are transgressed, and when advanced capitalism parks its tanks on the lawn of the everyday, these banal occurrences become important sites of reflection and critique.

However, there is one more consideration that motivated my decision to leave Facebook; not a negative property of Facebook, but something lacking with it. I will close by attempting to articulate what is in essence an ideology. Lyotard (2005) taught us to be incredulous towards metanarratives, opening up a plane of diverse and dissenting little narratives. The new media have proven invaluable in giving air-time to these previously unbroadcast perspectives; despite fears of the imposition of a set form to these expressions, we can at least see that things are moving in the right direction. But postmodernity is a continuing project of critique, and it is by going beyond Lyotard that we see the radical potential of our new technologies. Jacques Rancière (1999) notes a fundamental sameness at the heart of these different narratives: we are all speaking beings. From such a position we see that to deny others their voice, to condemn them to silence, is an injustice. Our communication technologies ought to be at the heart of this; the silence of others becomes a global concern, the granting of a voice to the voiceless likewise. That instead we have the twin vices of voyeurism and frictionless capitalism is a cause of regret.

\section{Endnotes}

1. I was helped to this conclusion in correspondence with Alex Carruth. 


\section{References}

Bauman, Zygmunt. 2008a. Community: Seeking Safety in an Insecure World. Cambridge: Polity Press.

—. 2008b. Liquid Modernity. Cambridge: Polity Press.

BBC News. 2009. "MI6 boss in Facebook entry row”, accessed August 24, 2009 (http://news.bbc.co.uk/1/hi/uk/8134807. stm).

Brabazon, Tara. 2008. Thinking Popular Culture: War, Terrorism and Writing. Farnham, Surrey: Ashgate.

Burrows, Roger and Nick Ellison. 2004. "Sorting places out? Towards a social politics of neighbourhood informatization", Information, Communication \& Society, 7:3, 321-336.

Burrows, Roger and Nicholas Gane. 2006. "Geodemographics, software and class”, Sociology, 40, 793-812.

Crang, Michael and Stephen Graham. 2007. "Sentient cities: ambient intelligence and the politics of urban space", Information, Communication \& Society, 10:6, 789-817.

Gane, Nicholas and David Beer. 2008. New Media: The Key Concepts. Oxford: Berg.

Graham, Stephen. 2005. “Software-sorted geographies”, Progress in Human Geography, 29:5, 562-580.

Hillis, Ken. 2009. Online a Lot of the Time: Ritual, Fetish, Sign. Durham, NC: Duke University Press.
Lyotard, Jean-François. 2004. The Inhuman: Reflections on Time. Translated by Geoffrey Bennington and Rachel Bowlby. Oxford: Polity Press.

-. 2005. The Postmodern Condition: A Report on Knowledge. Translated by Geoffrey Bennington and Brian Massumi. Manchester: Manchester University Press.

Newman, Saul. 2007. Unstable Universalities: Poststructuralism and Radical Politics. Manchester: Manchester University Press

Parker, Simon, Emma Uprichard, and Roger Burrows. 2007. "Class places and place classes: geodemographics and the spatialization of class", Information, Communication \& Society, 10:6, 902-921.

Rancière, Jacques. 1999. Disagreement: Politics and Philosophy. Translated by Julie Rose. London: University of Minnesota Press.

Virilio, Paul. 1998. Open Sky. Translated by Julie Rose. London: Verso.

Wellman, Barry and Milena Gulia. 1999. “Net Surfers don't ride alone". Pp. 167-194 in Communities in Cyberspace, edited by Marc A. Smith and Peter Kollock. London: Routledge.

Wikipedia. 2009. "Facebook Beacon”, accessed August 24, 2009. (http://en.wikipedia.org/wiki/Facebook_Beacon).

Žižek, Slavoj. 2008. Violence: Six Sideways Reflections. London: Profile Books. 
